PEDAGOGISK FORSKNING I SVERIGE Vol 25 No 4 (2020) ISSN 1401-6788

\title{
Debatt
}

\section{Praksisnær forskning og partnerskap i et tredje rom}

Tine S. Prøitz, Professor

Institutt for økonomi, historie og samfunnsvitenskap, Universitetet i SørøstNorge

Kontakt:Tine.proitz@usn.no

Sett med norske øyne er den svenske debatten om praktiknara forskning ytterst interessant og misunnelsesverdig. Den er interessant gjennom sin likhet med hvordan norske myndigheter over de siste tiår har vektlagt innsatser for at pedagogisk forskning skal bli mer praksisnær, anvendbar og dermed mer til nytte for skolen og lærerne. Misunnelsesverdig fordi vi i motsetning til Sverige på langt nær har den samme tradisjonen for en så uttalt debatt om hva det faktisk innebærer at den pedagogiske forskningen er praksisnær. Ved første øyekast synes det selvfølgelig at pedagogisk forskning skal være praksisnær for hva skulle den ellers være? Mange vil også hevde at forskingen de arbeider med i tilknytning til skoler, lærere og elever er nær praksis. Den svenske debatten synliggjør at det er et stadig behov ikke bare for å debattere hva praksisnær er, men også hva ropet etter praksisnær forskning er et uttrykk for. Hva søkes det å oppnå med praksisnær forskning? Hvem er aktørene som skal involveres og hvilke roller har de? Hvilke fordeler og ulemper fører slik forskning med seg for deres arbeid og ikke minst hvilke kunnskapsbidrag kan vi forvente? I dette innlegget kommer jeg ikke til å svare på alle disse spørsmålene. Jeg kommer til å peke på noen dilemmaer som følger av det jeg, paradoksalt nok i en tid med pandemi og sosial distansering, vil kalle narbetsbevegelsen og det som kanskje kan være et mulig veivalg i arbeidet med praksisnær forskning. 
Litteratur om forholdet mellom forskning og praksis er mangfoldig og fragmentert, noe som også reflekteres i det mangfold av begreper og forståelser som knyttes til tematikken (se for eksempel Serder \& Malmstrom, 2020; Persson, 2020). Et gjennomgående fellestrekk i myndigheters tiltak så vel som i forskningslitteraturen om praksisnær forskning synes imidlertid å være narbet. I forskningen og i politikken handler det gjennomgående om ordninger som har til hensikt å bringe organisasjoner, institusjoner, arenaer og aktiviteter nærmere sammen gjennom at folk faktisk og fysisk møtes. Det ser ut til å finnes en sterk tro på det å bringe folk med erfaring og kompetanse fra skole og akademia nær hverandre i det vi kan kalle nærhets-bevegelsen. Om vi anlegger et kritisk blikk kan det se ut til at det finnes en ide om at bare folk bringes sammen så vil de gjennom selve nærheten automatisk overføre eller besmitte hverandre med sine perspektiver. Dette til tross for at de aller fleste som arbeider $i$ utdanningssektoren vet at dette er en grov forenkling og at det kreves strukturer, ressurser, engasjement og langsiktig hardt arbeid.

I norsk, nordisk og internasjonal sammenheng ser vi eksempler på nærhetsbevegelsen i utviklingen av nye $\mathrm{PhD}$-utdanninger der stipendiater med lærerbakgrunn arbeider med sitt praksisorienterte prosjekt. Ofte må disse stipendiatene i kraft av å være forskning og praksis i en og samme person finne løsninger på komplekse forskning-praksis spørsmål alene og med liten støtte fra akademia (Prøitz \& Wittek, 2020). Vi ser det i forskningsutlysninger og -anslag og i nasjonale myndigheters satsinger på partnerskap mellom akademia/lærerutdanning og skole/kommune som i universitetsskoler i Norge (Faglig råd for lærerutdanning, 2020) og i ULF-forsöksverksamhet i Sverige (Prøitz m.fl., 2019; 2020). Et kjennetegn ved praksisnær forskning som bærende ide, er at den i liten grad eksplisitt problematiserer hva nærhet mellom folk konkret innebærer.

Det finnes for eksempel få studier som kan si noe entydig om hvilke samarbeidsformer mellom forskning og praksis som kan fungere godt. En mye referert studie fra amerikansk kontekst beskriver produktive forskningpraksissamarbeid som langsiktige, de har fokus på praksisproblemer, er preget av gjensidig forpliktelser, har strategier for å utvikle partnerskapene og utvikler originale analyser. Partnerskapene har stabile og hyppige møtepunkter som bidrar til å utvikle tillit og gjensidig forpliktelse og likeverdighet mellom partene. Gjensidighet i partnerskapet er viktig for å ivareta de involvertes perspektiver og etablering av kulturer for deling. Delte målsettinger, delte verdier, likeverdighet $\mathrm{i}$ autoritet og $\mathrm{i}$ arbeidet som gjøres fremheves som nødvendig (Coburn et al., 2013). Studier som har sett på samarbeid og partnerskap omkring praksisbasert kunnskapsutvikling og praksisbasert forskning, viser imidlertid at det er svært krevende å få til de nødvendige likeverdige og praksisnære relasjonene (Nutley m.fl., 2008). Dette handler blant annet om ulikheter i interesser og engasjement, manglende respekt og forståelse for andre kunnskapsområder så vel som ressursmessige, 
strukturelle og kulturelle barrierer som ofte trekker aktørene fra hverandre fremfor til hverandre. Dette er faktorer som har noe å si for realiseringen av den faktiske nærheten mellom aktørene, og det er faktorer som det ofte er krevende å endre på. I norsk sammenheng ser vi konkrete eksempler på hvordan den fysiske nærheten begrenses av læreres reelle muligheter til å delta i møter med forskere og kommuner. Lærerens tid bundet til klasserommet og skolen utfordrer forskningens og administrasjonens friere møtekulturer og dermed også hvordan det kan samarbeides. Satt på spissen, å få lærere med i et likeverdig arbeid kan være krevende når de ikke kan komme på møte. Like krevende kan det være å finne andre og nye møteplasser enn de man alltid har hatt.

Et teoretisk bidrag som forsøker å imøtekomme disse utfordringene og styrke forskning-praksis forholdet foreslår en såkalt "third space"/tredje rom tenkning (se for eksempel Passy, Georgeson \& Gompertz, 2018; Lynch, 2015; Whitchurch, 2012; Moje, Ciechanowski, Kramer, Ellis, Carrillo \& Collazo, 2004). Innenfor "third space" tenkning vektlegges ulike aktørers diskurser slik de er forankret i deres ulike kontekster i møtet med hverandre. Møtet mellom disse diskursene kan være produktive, men de kan også være begrensende for menneskelig aktivitet.

Tredje rom tenkning kan fungere som verktøy for å utvikle bedre forståelser av hva som trekker folk i praksisfeltet og forskningsfeltet sammen og hva som trekker dem fra hverandre, hva som skaper nærhet og hva som skaper distanse. Det tredje rommer er beskrevet som et rom der kunnskaper og diskurser fra ulike rom kan møtes og slås sammen $\mathrm{i}$ et tredje felles rom. Men kanskje ennå viktigere, er det at denne tenkningen kan hjelpe oss til å bli bevisst hvilke diskurser som dominerer og får forrang og hvilke som marginaliseres i praksisnær forskning. Tredje rom-tenkningen kan forstås som en måte å bygge broer mellom diskurser på, som en måte å navigere ulike miljøer av diskurser på og til sist som et rom der ulike og også konkurrerende ideer kan bringes sammen for å utfordre dominante og mindre konstruktive diskurser.

Politikkens initiativ og satsinger og forskingens diskusjoner kan ha en tendens til å tilsløre det faktum at praksisnær forskning legger til grunn faktiske møter mellom folk som vanligvis ikke har naturlig, fysisk nærhet til hverandre. Tredje rom perspektivene kan bidra til å identifisere uønskede faktorer mellom lærere, forskere og administrasjon i søken etter en konstruktiv og bærekraftig vei for forskning-praksis samarbeid i, for og om utdanning. 


\section{REFERENSER}

Coburn, Cynthia E., Penuel, William R., \& Geil, Kimberley E. (2013). Practice Partnerships: A Strategy for Leveraging Research for Educational Improvement in School Districts. William T. Grant Foundation. http://learndbir.org/resources/CoburnPenuel-Geil-2013.pdf

Faglig råd for lærerutdanning (2020) Partnerskap i lærerutdanningene - et kunnskapsgrunnlag, Kunnskapsdepartementet, Norge. https://www.regjeringen.no/contentassets/9969c3f46f0c4a4f95ed9eee70b3ed19/ partnerskap-i-larerutdanningene---et-kunnskapsgrunnlag.pdf (2020-09-20)

Lynch, Timothy (2015). Teacher education physical education: In search of a hybrid space. Cogent Education, 2(1), 1027085. https://doi.org/10.1080/2331186X.2015.1027085

Moje, Elizabeth B., Ciechanowski, Kathryn M., Kramer, Katherine, Ellis, Linday, Carrillo, Rorario, \& Collazo, Tehani (2004). Working toward third space in content area literacy: An examination of everyday funds of knowledge and discourse. Reading research quarterly, 39(1), 38-70. https://doi.org/10.1598/RRQ.39.1.4

Nutley, Sandra, Jung, Tobias, \& Walter, Isabel (2008). The many forms of researchinformed practice: a framework for mapping diversity. Cambridge Journal of Education, 38(1), 53-71. https://doi.org/10.1080/03057640801889980

Passy, Rowena, Georgeson, Jan, \& Gompertz, Beth (2018). Building learning partnerships between schools and universities: an example from south-west England. Journal of Education for Teaching, 44(5), 539-555.

https://doi.org/10.1080/02607476.2018.1516346

Persson, Anders (2020). Dubbel närhet och distans behövs i praktiknära forskning. Pedagogisk. Forskning i Sverige, 25(2-3), 149-152.

https://doi.org/10.15626/pfs25.0203.07

Prøitz, Tine S. Aasen, Petter og Barstad, Kristin (2019) Utbildning, lärande, forskning: en evalueringsstudie-delrapport 1. USN Skriftserie 19/19.

http://hdl.handle.net/11250/2587787

Prøitz, Tine S., Rye, Ellen M., Barstad, Kristin, Afdal, Hilde, Risan, Maiken, \& Aasen, Petter (2020). Utbildning, lärande, forskning-en evalueringsstudie-delrapport 2. USN Skriftserie 38/20. https://hdl.handle.net/11250/2641753

Prøitz, Tine S., \& Wittek, Line (2020). New directions in doctoral programmes: bridging tensions between theory and practice?. Teaching in Higher Education, 25(5), 560-578. https://doi.org/10.1080/13562517.2019.1577813

Serder, Margareta, \& Malmström, Martin (2020). Vad talar vi om när vi talar om praktiknära forskning?. Pedagogisk forskning i Sverige, 25(1), 106-109. https://doi.org/10.15626/pfs25.01.07

Whitchurch, Celia (2012). Reconstructing identities in higher education: The rise of 'third space' professionals. New York, London: Routledge. 